\title{
Original Research Article On English Listening Learning Strategies for College Students
}

\author{
Xiaomei Zhang \\ Xi'an FANYI University, 710105
}

\begin{abstract}
In recent years, the reform of college education and teaching introduced by the state has achieved remarkable results, and college English curriculum has been repositioned as an important course. Oral English is one of the important contents of college students' foreign communication. As a second language, the environment of English teaching lags behind Chinese, which is very difficult for contemporary college students to master oral English skills. Especially the English listening part is the premise for college students to understand oral English, and the quality of listening ability directly affects the ability of college students to understand English. Although the English teaching reform has increased the content of listening training to some extent, it is due to the difference of language environment and learning. The platform is backward, the listening effect of college students is still unsatisfactory. Based on the present situation of college students' listening, this paper discusses how to effectively reform and improve the effect of college students' English listening learning.
\end{abstract}

Keywords: College Students; English Listening; Learning Strategies

\section{Introduction}

English is the basic skill that college students must master under the condition of opening to the outside world in our country. The study of listening skills can not only improve students' language skills, but also enrich students' English vocabulary and help students master the basic ${ }^{[1]}$ of English grammar structure. At present, the most basic teaching methods in college English are the whole body reaction method, which mainly ensures the consistency of students' English learning through the dual cultivation of listening and language expression ability. However, because of the short duration of English courses and the relatively difficult listening materials, it is difficult for students to like listening training.

\section{Factors affecting college students' English listening learning}

\subsection{Disadvantages of traditional English teaching}

In the traditional course teaching process, teachers think that the most important teaching goal is to help students master the ability of writing and reading, without considering the importance of listening learning to students. In the middle and high school English learning, most of the students' English learning materials are only written tutorials, and students can improve their test results through the training of relevant skills. However, after entering the university, the score of listening in the CET-4 and CET-6 examination is gradually improved, the input quantity is large, and the attention requirement of the students is higher, which leads to the students' written skills can not cope with the listening training in the university.

\subsection{Characteristics of students' listening}

Listening comprehension is a part of the content that most college students are difficult to master. Because of the difference of educational resources in various regions, the reserve of students' basic English knowledge is also different. In addition, some students only listen to English by deep memory of key words, but because their attention can not be completely focused on longer listening training, so students are likely to miss key words. This learning method is very inefficient. Some students' vocabulary is not sufficient, so they can not understand the content of listening correctly. Some students are used to speaking English in dialects. As a result, the pronunciation of words is wrong and the sense of language is not strong, which leads to the contradiction between students' learning strategies and their own characteristics.

\subsection{Abstract of hearing material}

English listening materials include common sense of life, communicative dialogue, tongue twisters, academic research and so on. They cover a wide range, and when playing with electronic equipment, the sentences in listening materials can not be completely presented to students because of the interference of technical means. In addition, the listening materials of universities are abstract compared with junior high schools, mostly around professional communication, changing the traditional training

Copyright (C) 2020 Xiaomei Zhang

doi: 10.18282/1-e.v9i2.1402

This is an open-access article distributed under the terms of the Creative Commons Attribution Non-Commercial License

(http://creativecommons.org/licenses/by-nc/4.0/), which permits unrestricted non-commercial use, distribution, and reproduction in any medium, provided the original work is properly cited. 
around familiar topics for students. As a result, students can not write the professional vocabulary they hear in time. In addition, students usually avoid difficult sentences in the process of speaking and writing, resulting in students' ability. The force has been at the low end level.

\section{Strategies of English listening ability training for college students}

\subsection{Selection of hearing materials}

When choosing listening materials, teachers need to combine students' own English characteristics and English ability, follow the law of students' English development, choose different listening materials in different periods, and improve students' interest in English materials at various stages. At present, it is difficult for college students to master the listening materials with fast speech speed and large amount of new words, combined with the difference of cultural background knowledge, it is difficult for students to mobilize the language knowledge in their brains in a limited time. Therefore, teachers need to provide listening materials step by step. In the initial stage of students' ability, they can start with simple words and phrases, look for listening materials related to students' life experience, and help them learn Students enter the real life situation to grasp the main idea of the article, help students to clear up the learning ideas of English listening, lay the foundation for the later listening training, and gradually transition to paragraphs and even the full text according to the characteristics of the students. Listening materials can collect relevant film and television sound, English songs and question bank materials to help students analyze the humanistic literacy in the materials sentence by sentence, grasp the ideological connotation, and further help students unconsciously master English pronunciation.

\subsection{Timing of hearing duration}

Because college students have more homework and practical activities, most students do not insist on the habit of English listening training, and the students' learning tasks can only be completed according to the arrangement of teachers. This is very unfavorable to the cultivation of students' sense of language. Therefore, teachers can guide students to learn independently in their spare time, and use fragmented time, such as on the way to class, climbing stairs or taking a break in self-study class, to accumulate English listening. In addition, teachers can use campus radio stations, school curriculum learning platform to help students unconsciously contact English content, so that students don't feel boring because of special training. Flexible listening time can not only improve students' language expression ability, but also help students to form a sense of English language over time, and can mobilize the contents heard in daily life when they come into contact with materials.

\subsection{Training in listening skills}

There are many methods of listening skills, including listening, listening and speaking dialogue, dictation and listening comprehension. Teachers need to make use of interesting language materials in their daily life to create a real English language environment, so that students can do listening and speaking training anytime and anywhere, and cultivate students' English language sense $^{[2]}$. As with Chinese, English listening also needs to be achieved according to interpersonal communication. Therefore, teachers need to summarize language materials containing grammatical content in the process of guiding students to learn. Let students learn relevant grammar and words while contacting materials. In addition, teachers can use functional English materials, such as Reading materials help students expand the vocabulary reserve and make students reasonably infer the logical relationship of the article. At the same time, we should pay attention to the habit of students' English expression, correct the students' wrong grammar seriously, and let students dare to communicate and discuss with other students in their daily life. Teachers can also make full use of the dialogue, stories and other materials provided in the teaching materials to make students familiar with the pronunciation and intonation of English, to help students standardize their daily language, and to use their communication ability to promote their listening ability.

\subsection{Changes in teaching methods}

The change of teachers' teaching methods can help students to carry out systematic English listening training. Therefore, teachers can create scientific listening training methods for students according to their learning stage. Teachers can first use English to organize teaching in class, and at the same time use humorous English language to deepen students' impression of English. By creating interesting situations to help students perceive language in practice. Teachers can use Internet content to arouse students' awareness of English language expression in the classroom, use Internet technology to display the historical customs of Englishusing countries, let students describe them again, and improve students' understanding in real context Participation in learning. In addition, teachers need to use role-playing, simulated dialogue and so on to make students feel different from Chinese expression, to help students find their own weak points of English knowledge. Teachers can also create relevant practical activities, use the international academic exchanges of the school to communicate with foreign friends in depth, help students understand the real English language flow, and improve students' effective recognition of fuzzy words in English materials.

\section{Conclusion}

In a word, teachers need to use their spare time to train students independently from the perspective of college students, to enrich students' English vocabulary and to ensure the all-round development of students' listening, speaking, reading and writing skills. Avoid isolated learning and mechanical training in the teaching process.

\section{References}

1. Yang Lilan. A Probe into College English Listening Teaching Based on English Film [J]. English for Middle School Students ,2019, 000(048): P.80-81.

2. Liu Yunhua. A Strategy for Improving the Listening Level of Non-English Major Students in [J]. University Journal of Western Fujian Vocational and Technical College, 2020, 022(001): 112-116. 